\title{
Policy framework and legal forms of social enterprise in Central and Eastern Europe
}

\author{
Daniela STAICU \\ The Bucharest University of Economic Studies, Bucharest, Romania \\ danielastaicu@gmail.com
}

\begin{abstract}
In Central and Eastern European countries, the transition to a market economy stimulated civil society initiatives that in the past had been either discouraged or had become part of the Communist state system, and opened new pathways to entrepreneurial initiatives. The 1990s was an open window to the creation of a significant number of non-profit organizations, including the pioneering establishment of the first social enterprises. When these countries became members of the European Union, the process of legal institutionalization of social enterprises started to be discussed and has taken place at various stages. The purpose of this paper is to provide a comprehensive overview of the policy frameworks and the legal forms and of social enterprises in eight countries: Bulgaria, Croatia, the Czech Republic, Hungary, Poland, Romania, Slovakia, and Slovenia. The research seeks to determine the extent to which the development of national policy frameworks influences the development of legal forms under which social enterprises operate. For the purpose of this analysis, data were collected from relevant to this subject country reports, studies, laws released between 2009 and 2016. The research shows that European social enterprises are often 'hidden' among existing legal forms either as associations and foundations with commercial activities, cooperatives serving general or collective interests and mainstream enterprises pursuing an explicit and primary social aim. Further research needs to be done to determine the potential for growth of entities operating as associations and foundations with commercial activities. Furthermore, the research concluded that the countries with specific laws on social entrepreneurship generate $61 \%$ of the social economy activity in Central and Eastern European countries. Further research needs to be done to determine if introducing a social enterprise specific legal form, will stimulate the development of the business models under which social enterprises operate and implicitly growth.
\end{abstract}

Keywords: social economy, social enterprise, Central and Eastern Europe, policy framework, legal form, social aim.

\section{Introduction}

Emerging from decades of state economic control, countries in Central and Eastern Europe (CEE) privatized industries in various paces, introduced competition, and tapped the talents of their people to raise gross domestic product and living standards. (Labaye et al., 2013). Privatization has been a particularly important phenomenon in the transition process of planning to a market system. Communist regimes had placed almost all the productive assets of the economy into state hands for ideological reasons, and to facilitate the planning process. As a result, countries like Czechoslovakia contained virtually no private sector at all - typically in excess of $90 \%$ of assets were state owned - and even in countries with slightly larger private sectors, like Poland or Hungary, private ownership was concentrated in agricultural and handicraft activities; industrial firms were all in state hands (Estrin, 2007). The shock of economic change of state economy to private economy, the privatization of enterprises, the opening of markets to foreign competition and in consequence the breakdown of entire branches of national economies (e.g. shipbuilding in 
Poland, the Czech and Slovenian textile industry; the sell-off of entire economic sectors to foreign capital), caused social differentiation and exclusion (Selih and Zavrsnik, 2012).

The current paper aims to determine the extent to which the development of national policy frameworks influences the creation of new legal forms and the status of legal forms under which social enterprises already operate. Also, correlations between nongovernmental organizations (NGOs) undertaking economic activity, and NGOs in general are analyzed. The paper starts with a review of the European Union operational definition of social enterprise. Then it explains how the application of this definition at national levels in the countries studied, impacts the legal forms under which social enterprises already run under, and it continues with an analysis between the national policy frameworks and the degree of development of new legal forms in correlation with the policy frameworks. Finally, conclusions are drawn based on results.

\section{Literature review}

\section{Operational definition of social enterprise}

National economies are considered to have three sectors. The first sector is the private sector which is centered on profits for private purposes and the second sector or the public sector is overseen by governments. However, national economies have a third sector that does not fit into either of the preceding categories and is also seen as part of what is known as the social economy (O'Byrne et al., 2015). Recent years have seen a burgeoning interest in social enterprise across Europe, strongly driven by a growing recognition of the role social enterprise can play in tackling societal and environmental challenges and fostering inclusive growth (European Commission, Directorate-General for Employment, Social Affairs and Inclusion, 2016). A social enterprise involves all employees, consumers and third parties which are affected by its social and economic activities (Păunescu et al., 2016). Impetus has come also from the 2009 global economic crisis which has resulted in widespread public discontentment with the functioning of the global economic system and fueled interest in more inclusive and pluralistic economic systems (European Commission, 2014a).

Social economy enterprises represent $10 \%$ of all European businesses, with 2 million social enterprises and 6\% of EU's employment (Social economy in the EU, 2017). These developments demonstrate that the Social Economy has become a key element of the European social model and a key player in attaining the objectives set out in the EU 2020 Strategy. According to the South-East Europe 2020 Strategy, the 'Employment' dimension addresses labor mobility, labor market governance and promotion of social economy activities as the main priorities (Regional Cooperation Council, 2013). Moreover, demonstrating its growing policy relevance, the European Commission has recently issued a comprehensive guide to the social economy and social entrepreneurship. The guide outlines the context in which the social economy and social entrepreneurship are situated. Essentially what emerges here is that social enterprises occupy a place in member state economies that is distinct from the more traditional private and public sectors and is extremely important in the European context (European Commission Directorate-General for Employment, Social Affairs and Inclusion, 2013). Yet, despite interest in and the emergence of social enterprise, relatively little is known about the policy framework and the legal forms under which social enterprises operate in the emerging social enterprise sector in CEE. 
The definition developed by the European Commission as part of the Social Business Initiative which run from 2011 to 2014, could be used to distinguish social enterprises from mainstream enterprises and traditional social economy entities. (European Commission, 2014a). These are private organizations that typically pursue goals other than profit: their main purpose is not to generate financial gains for their owners or stakeholders but to provide goods and services either to their members or to the community at large (European Commission Directorate-General for Employment, Social Affairs and Inclusion, 2013). This definition incorporates the three key dimensions of a social enterprise that have been developed over the last decade through a body of European academic and policy literature (country reports, studies, laws, regulations): an entrepreneurial dimension, a social dimension, a governance dimension Each of the above dimensions were operationalized by developing a set of core criteria that an organization must meet in order to be categorized as a social enterprise under the European Union definition (European Commission, 2014a).

The most prevalent core criteria found in the literature review (Table 1) are related to the governance dimension which concerns the existence of mechanisms to 'lock in' the social goals of the organization: (1) limits on distribution of profits ( $n=26 \%)$; (2) independence or autonomy from the State and other traditional for profit organizations ( $n=26 \%),(2)$ inclusive governance characterized by participatory and/ or democratic decision-making processes $(n=20 \%)$. The least mentioned core criteria regard the entrepreneurial dimension: it must engage in a continuous activity of production and/or exchange of goods and/or services ( $n=13 \%)$ (European Commission, 2014a).

Table 1. Frequency of core criteria related to social enterprise found in the literature (2009-2016)

\begin{tabular}{|l|l|l|l|l|}
\hline $\begin{array}{l}\text { Social enterprise } \\
\text { dimension } \\
\text { (European } \\
\text { Commission, } \\
\text { 2014a) }\end{array}$ & $\begin{array}{l}\text { Core criteria that an organization } \\
\text { must meet to be categorized as a } \\
\text { social enterprise (European } \\
\text { Commission, 2014a) }\end{array}$ & References & Sources & Frequency \\
\hline Entrepreneurial & economic activity & 35 & 270 & $13 \%$ \\
\hline Social & social aim & 20 & 132 & $15 \%$ \\
\hline \multirow{3}{*}{ Governance } & limits on distribution of profits & 9 & 35 & $26 \%$ \\
\cline { 2 - 5 } & be independent & 33 & 126 & $26 \%$ \\
\cline { 2 - 5 } & inclusive governance & 10 & 49 & $20 \%$ \\
\hline
\end{tabular}

Source: Authors' own processing.

\section{Methodology}

To achieve its main goal, the paper has three major objectives: (1) To determine the variety of legal forms complying with the EU operational definition for social enterprise under which social enterprises in the countries examined operate; (2) to determine the level of development of policy frameworks for social entrepreneurship in the countries studied; (3) to examine the influence of national policy frameworks development on legal forms for social enterprise.

For this purpose, the data was collected from relevant country reports, studies, laws: country reports published by the European Commission and elaborated under the title: "A map of social enterprises and their eco-systems in Europe, Country report" for each of the countries examined. Each report provides a non-exhaustive overview of the social enterprise landscape in each country studied, based on available information as of 2014 up to 2016, depending on country. The reports mention that although a range of stakeholders 
were interviewed to verify, update and supplement the information collected from secondary sources, it was not possible to consult all relevant stakeholders within the constraints of the study; UNDP 2012 report "Legal Framework for social economy and social enterprises: A comparative report" (European Center for Not-for-Profit Law, 2012); McKinsey Global Institute report released in 2013 "A new dawn: Reigniting growth in Central and Eastern Europe"; and European Commission report on "Social economy and social entrepreneurship, Social Europe guide, Volume 4" released in 2013. The criteria used for analysis concerned legal forms, and national policy frameworks for SE.

The selection of the reports, studies, and laws was done based on the date of release, only information published since 2011 was being considered for analysis. Still, the diversity of national economic structures, and legal frameworks has meant that measuring and comparing social enterprise activity across Central and Eastern Europe is a challenge due to the lack of availability and consistency of statistical information on social enterprises across Europe.

\section{Results and discussion}

Application of the $E U$ 'operational definition' to national legal forms of social enterprise The analysis reveals that several countries have institutionalized the concept of social enterprise either by creating a transversal legal status or tailor made legal forms of social enterprise (Table 2). The data collected and interpreted concerns all legal forms under which SE currently operates in each of the countries examined. Data were extracted from the country reports released by the European Commission between 2014 and 2016. All the legal forms included in the analysis comply with the EU operational definition of SE and entities functioning under these legal forms were validated as social enterprises although national policy framework is not in place in all countries examined: (1) Specialized enterprises and cooperatives for people with disabilities; (2) NGOs undertaking some economic activity; (3) Social enterprises; (4) Mutual aid associations for pensioners; (5) Cooperatives; (6) Limited liability Company/Non-profit companies with social aims; (7) Public benefit organizations, and civic associations). Legal forms employed in a single country (mutual aid associations for pensioners in Romania; Public benefit organizations, and civic associations in the Czech Republic), were included in the analysis in order to map the variety of legal forms under which SE runs.

Table 2. Specific legal forms or status for social enterprise in CEE

\begin{tabular}{|l|l|l|l|l|l|l|l|l|}
\hline $\begin{array}{l}\text { Country/ } \\
\text { SE Legal form }\end{array}$ & $\mathbf{( 1 )}$ & $\mathbf{( 2 )}$ & $\mathbf{( 3 )}$ & $\mathbf{( 4 )}$ & $\mathbf{( 5 )}$ & $\mathbf{( 6 )}$ & $\mathbf{( 7 )}$ & Total \\
\hline Bulgaria & 125 & 85 & 0 & 0 & 251 & 0 & 0 & 461 \\
\hline Croatia & 0 & 4200 & 0 & 0 & 27 & 0 & 0 & 4227 \\
\hline The Czech Republic & 0 & 0 & 0 & 0 & 0 & 90 & 74 & 164 \\
\hline Hungary & 0 & 400 & 0 & 0 & 600 & 1600 & 0 & 2600 \\
\hline Poland & 260 & 4500 & 0 & 0 & 195 & 0 & 0 & 4955 \\
\hline Romania & 372 & 4058 & 0 & 2780 & 0 & 0 & 0 & 7210 \\
\hline Slovakia & 2571 & 1098 & 52 & 0 & 0 & 0 & 0 & 3721 \\
\hline Slovenia & 142 & 831 & 56 & 0 & 0 & 0 & 0 & 1029 \\
\hline Total number & 3470 & 15172 & 98 & 2780 & 1073 & 1690 & 74 & 24357 \\
\hline
\end{tabular}




\begin{tabular}{|l|l|l|l|l|l|l|l|l|}
\hline $\begin{array}{l}\text { Total number of } \\
\text { countries with } \\
\text { using this specific } \\
\text { legal form for SE }\end{array}$ & 5 & 7 & 3 & 1 & 4 & 2 & 1 & $\begin{array}{l}\text { Not } \\
\text { applicable }\end{array}$ \\
\hline
\end{tabular}

Source: Authors' own processing.

Organizations fulfilling the 'EU operational definition' of social enterprise as defined in Table 1 can be found in all 8 countries examined where social enterprises adopt a variety PICBE | 879 of legal forms and statuses: (a) the most popular legal form of SE is non-governmental organization undertaking some economic activity present in seven out of eight countries; (b) a few countries, have specific legal forms for development of social economic activity, present only in those countries (The Czech Republic recognizes as SE public benefit organizations and civic associations (European Commission, 2014f) while mutual aid associations for pensioners is specific to Romania, and assists their members by granting loans at low interest rates, provide social, cultural and touristic services, being regulated by Law 540/2002 (European Commission, 2014c), regulation which is not under the Social Entrepreneurship law; (c) specialized enterprises and cooperatives for people with disabilities exist in five of the eight countries and narrowly focuses on work integration social enterprises which excludes enterprises pursuing societal missions such as provision of social and educational services, environment, well-being for all (European Commission, Directorate-General for Employment, Social Affairs and Inclusion, 2016); (d) countries recognize the social purpose of cooperatives in their existing legislation covering cooperatives: Croatia, Czech Republic, Hungary; (e) new legal forms exclusively designed for social enterprises by adapting existing legal forms e.g. social enterprises in Slovenia (European Commission, 2014d) and Slovakia (European Commission Directorate-General for Employment, Social Affairs and Inclusion, 2016).

European social enterprises are often 'hidden' among three categories of legal forms (Table 2): (a) associations and foundations with commercial activities ( $n=15172$ nongovernmental organizations undertaking some economic activity); (b) Cooperatives serving general or collective interests $(n=4543)$; (c) Mainstream enterprises pursuing an explicit and primary social aim (n=4568 social enterprises, mutual aid associations for pensioners, limited liability company/non-profit companies with social aims).

Though the most popular legal form of SE are non-governmental organizations undertaking some economic activity (Table 2), the percentage of those who tackle the entrepreneurial dimension out of the total of non-governmental organizations is low (Table $3, \mathrm{n}=0,24 \%$ in Bulgaria (European Commission, 2014b)). One exception is Hungary where $100 \%$ of the non-governmental organizations have an economic dimension because Hungary has another legal form employed by NGO's: non-profit companies with social aims, which often receive an acknowledgement of their 'public benefit' status from the state - this comes with benefits but also with the prohibition of profit distribution (European Commission, 2014g). 
Table 3. NGO's level of activity as $S E$

\begin{tabular}{|l|l|l|l|l|l|l|l|l|}
\hline $\begin{array}{l}\text { Legal } \\
\text { forms/ } \\
\text { Country }\end{array}$ & Bulgaria & Hungary & Slovenia & Slovakia* & Romania & Croatia & Poland & $\begin{array}{l}\text { The Czech } \\
\text { Republic }\end{array}$ \\
\hline $\begin{array}{l}\text { NGOs } \\
\text { undertaking } \\
\text { some } \\
\text { economic } \\
\text { activity }\end{array}$ & 85 & 400 & 831 & 750 & 4058 & 4200 & 4500 & $\begin{array}{l}\text { no } \\
\text { information }\end{array}$ \\
\hline $\begin{array}{l}\text { NGOs } \\
\text { (in total) }\end{array}$ & 35000 & 400 & 23075 & 37600 & 33670 & 46000 & 75000 & $\begin{array}{l}\text { no } \\
\text { information }\end{array}$ \\
\hline Percentage & $0,24 \%$ & $100,00 \%$ & $3,60 \%$ & $1,99 \%$ & $12,05 \%$ & $9,13 \%$ & $6,00 \%$ & $\begin{array}{l}\text { no } \\
\text { information }\end{array}$ \\
\hline
\end{tabular}

Source: Authors' own processing.

Further investigation needs to be done to identify the factors which determine an entrepreneurial drive among non-governmental organizations in CEE.

\section{National policy framework on social enterprise}

Social economy has the potential to play an even greater role in increasing well-being and prosperity if appropriately supportive mechanisms are in place. In countries where the social economy is under-developed, or lacks support, there is the need to raise its profile and the support it receives by designing frameworks which enable it to develop and flourish, thereby enhancing its contribution to fostering and improving social inclusion (OECD/Noya and Clarence, 2008).

Three out of eight CEE countries studied do not have a specific policy framework for supporting the development of social enterprise, although all three are in the process of developing one (see Table 4).

Table 4. National policy frameworks for SE status

\begin{tabular}{|c|c|c|c|c|}
\hline Country & Policy framework for SE & $\begin{array}{l}\text { Under } \\
\text { development } \\
\text { at various } \\
\text { stages }\end{array}$ & Law & $\begin{array}{l}\text { Existence } \\
\text { of legal } \\
\text { form } \\
\text { 'social } \\
\text { enterprise' }\end{array}$ \\
\hline Bulgaria & $\begin{array}{l}\text { National Social Economy concept and Action } \\
\text { plan on Social Economy 2014-2015 }\end{array}$ & Yes & $\mathrm{n} / \mathrm{a}^{*}$ & No \\
\hline Croatia & $\begin{array}{l}\text { Strategy for Social Entrepreneurship 2014- } \\
2020\end{array}$ & Yes & $\mathrm{n} / \mathrm{a}$ & No \\
\hline $\begin{array}{l}\text { The Czech } \\
\text { Republic }\end{array}$ & Commercial Corporations Law n. 90/2012 Coll & $\mathrm{n} / \mathrm{a}$ & Yes & No \\
\hline Hungary & $\begin{array}{l}\mathrm{X} / 2006 \text { law on cooperatives Governmental } \\
\text { decree on social cooperatives }\end{array}$ & $\mathrm{n} / \mathrm{a}$ & Yes & No \\
\hline Poland & $\begin{array}{l}\text { Draft National Programme of Social Economy } \\
\text { Development (KPRES) } 2014\end{array}$ & Yes & $\mathrm{n} / \mathrm{a}$ & No \\
\hline Romania & Law $219 / 2015$ on Social Economy & $\mathrm{n} / \mathrm{a}$ & Yes & No \\
\hline Slovakia & $\begin{array}{l}\text { Act no. 5/2004 on Employment Services, } \\
\text { consolidated on } 01.09 .2008\end{array}$ & $\mathrm{n} / \mathrm{a}$ & Yes & Yes \\
\hline Slovenia & Law on social entrepreneurship (SOCP)/2011 & $\mathrm{n} / \mathrm{a}$ & Yes & Yes \\
\hline
\end{tabular}

$\mathrm{n} / \mathrm{a}^{*}=$ not applicable

Source: Authors' own processing. 
Altogether the five countries which already have a law for social enterprise (Table 4), accommodate $61 \%$ of the total social enterprises in CEE countries studied. These numbers suggest that the existence of a policy framework supports the development of social economy structures. Where policies exist, they differ widely in scope, coverage and content.

\section{Conclusions}

European social enterprises are often 'hidden' among existing legal forms: (a) associations and foundations with commercial activities; (b) cooperatives serving general or collective interests (c) mainstream enterprises pursuing an explicit and primary social aim. Among these, associations and foundations with commercial activities have the highest activity as social enterprise, up to $62 \%$ out the total number of entities operating under legal forms which comply with the EU definition of social enterprise. However, these only represent $6 \%$ of the total of non-governmental organizations operating in the countries examined. Further investigation needs to be done to determine the factors which generate an entrepreneurial drive among non-governmental organizations in CEE.

The development of national policy frameworks targeting social entrepreneurship is a lengthy process. Research proved that the countries with specific laws on social entrepreneurship account for $61 \%$ of the social economy in CEE. Not enough attention is payed to the development of a specific social enterprise as legal form as only two countries have introduced so far. Further research needs to be done to determine the benefits of such legal form for business models under which the social enterprises operate and implicitly their growth.

\section{References}

Estrin, S. (2007). The Impact of Privatization in Transition Economies. New Palgrave Dictionary of Economics, 2nd Edition, 02-03. doi: 10.1057/9780230226203.1344.

European Center for Not-for-Profit Law. (2012). Legal Framework for Social Economy and Social Enterprises: A comparative Report. Retrieved from European Center for Notfor-Profit Law Website:http://ecnl.org/dindocuments/442_ECNL\%20UNDP\%20So cial\%20Economy\%20Report.pdf.

European Commission Directorate-General for Employment, Social Affairs and Inclusion. (2013). Social economy and social entrepreneurship, Social Europe guide, Volume 4. Luxembourg: Publications Office of the European Union.

European Commission. (2014a). A map of social enterprises and their eco-systems in Europe: Executive Summary. Retrieved from European Commission, Employment, Social Affairs \& Inclusion Website: http://ec.europa.eu/social/BlobServlet?docId= 12988\&langId=en.

European Commission. (2014b). A map of social enterprises and their eco-systems in Europe, Country Report: Bulgaria. Retrieved from European Commission, Employment, Social Affairs \& Inclusion Website: http://ec.europa.eu/social/Blob Servlet?docId=12990\&langId=en.

European Commission. (2014c). A map of social enterprises and their eco-systems in 
Europe, Country Report: Romania. Retrieved from European Commission, Employment, Social Affairs \& Inclusion Website: http://ec.europa.eu/social/Blob Servlet?docId $=13095$ \&langId $=$ en.

European Commission. (2014d). A map of social enterprises and their eco-systems in Europe, Country Report: Slovenia. Retrieved from European Commission, Employment, Social Affairs \& Inclusion Website:

PICBE $\mid 882$ http://ec.europa.eu/social/BlobServlet?docId=13000\&langId=en

European Commission. (2014e). A map of social enterprises and their eco-systems in Europe, Country Report: Slovakia. Retrieved from European Commission, Employment, Social Affairs \& Inclusion Website.

European Commission. (2014f). A map of social enterprises and their eco-systems in Europe, Country Report: Czech Republic. Retrieved from European Commission, Employment, Social Affairs \& Inclusion Website: http://ec.europa.eu/social/BlobServlet?docId=13101\&langId=en.

European Commission. (2014g). A map of social enterprises and their eco-systems in Europe, Country Report: Hungary. Retrieved from European Commission, Employment, Social Affairs \& Inclusion Website: http://ec.europa.eu/social/Blob Serv let?docId=13103\&langId=en.

European Commission Directorate-General for Employment, Social Affairs and Inclusion. (2016). Social enterprises and their Eco-systems: developments in Europe. Luxembourg: Publications Office of the European Union.

European Commission. (2016a). A map of social enterprises and their eco-systems in Europe, Country Report: Poland. Retrieved from European Commission, Employment, Social Affairs \& Inclusion Website: http://ec.europa.eu/social/BlobServlet?docId=16381 \&langId=en.

European Commission. (2016b). A map of social enterprises and their eco-systems in Europe, Country Report: Croatia. Retrieved from European Commission, Employment, Social Affairs \& Inclusion Website: http://ec.europa.eu/social/Blob Servlet?docId=12991\&langId=en.

European Commission Directorate-General for Employment, Social Affairs and Inclusion. (2016c). Social enterprises and their eco-systems: A European mapping report Updated country report: Slovakia. Retrieved from European Commission, Employment, Social Affairs \& Inclusion Website: ec.europa.eu/social/BlobServlet? docId=16382\&langId $=$ en.

Labaye, E., Sjåtil, P.E., Bogdan, W., Novak, J., Mischke, J., Fruk, M., Ionuțiu, O. (2013). A new dawn: Reigniting growth in Central and Eastern Europe. Retrieved from McKinsey Global Institute Website: http://www.mckinsey.com/global-themes/europe/a-newdawn-reigniting-growth-in-central-and-eastern-europe .

O’Byrne, D., Lean, J., Moizer, J., Walsh, P., Dell'Aquila, E., Friedrich, R. (2015). Social Enterprise in the European Union: A Review of Policy. Soc \& Pub. Pol. Rev. 9, 1 University of Plymouth Press, 15-16. Retrieved from https://www.researchgate.net.

OECD/Noya, A., Clarence, E. (2008). Improving social inclusion at the local level through the social economy. Retrieved on The Organisation for Economic Co-operation and Development Website: http://www.oecd.org/employment/leed/44688716.pdf.

Păunescu, C., Pascu, A.I., Pop, O. (2016). Întreprinderea socială: cum se distinge acest mod de a face afaceri față de alte întreprinderi?/ Social Enterprise: How does this Way of 
doing Business differ from other Forms of Enterprise. Calitatea. Acces la succes/ Quality. Access to Success(Scientific Journal of Management Systems (CSRAC), 17(153), 23-27/108-110.

Regional Cooperation Council. (2013). South East Europe 2020 - Jobs and Prosperity in a European Perspective. Retrieved from Regional Cooperation Council Website: http://www.rcc.int/files/user/docs/reports/SEE2020-Strategy.pdf.

PICBE | 883

Šelih, A., Završnik A. (2012). Crime and Transition in Central and Eastern Europe. New York, NY: Springer Science + Business Media.

Social economy in the EU [Web log post]. (2017, February 22). Retrieved from https://ec.europa.eu/growth/sectors/social-economy_en. 